Pendas : Jurnal Ilmiah Pendidikan Dasar, ISSN Cetak : 2477-2143 ISSN Online : 2548-6950 Volume III Nomor 2, Desember 2018

\title{
KESIAPAN SEKOLAH DALAM MENGIMPLEMENTASIKAN KEBIJAKAN KURIKULUM 2013 DI SDN NGRECO KEDIRI
}

\author{
Muh Saiful Anam \\ STAIN Kediri \\ putrasyaifu165@gmail.com
}

\begin{abstract}
The data of this study were taken from the results of the observation method, interviews with the Principals of Ngreco Kediri Elementary School, Homeroom 5. Preparedness of the 2013 Curriculum at Ngreco Kediri Elementary School, in the pre-research observations carried out by researchers showed an indication that the 2013 curriculum had begun to be applied at Ngreco Kediri Elementary School . The application of the 2013 curriculum according to researchers deserves further study. The purpose of this study was to find out: (1) To find out the mastery of the Principal, and the teacher about the 2013 curriculum. (2) To find out the school readiness in implementing the 2013 curriculum. (3) To find out the 2013 curriculum implementation by teachers in the learning process . (4) To find out the obstacles faced by schools in implementing 2013 Curriculum and what solutions are taken to overcome them. This type of research is qualitative. The primary data source in this study is the result of interviews with the Principal, the class teacher. Data collection techniques using interview, observation, and documentation techniques. The data analysis technique uses Moleong analysis. The results of this study can be concluded: (1) School readiness in the 2013 Curriculum at Ngreco Kediri Elementary School, by adjusting the content contained in the 2013 curriculum, namely: the objectives of the education unit, curriculum structure, Core Competencies, Basic Competencies, subject competencies, learning burdens, reinforcement governance, strengthening of material, and characteristics of the 2013 curriculum, (2) teacher readiness for the application of the 2013 Curriculum at Ngreco Kediri Elementary School. Based on the results of this study, it is hoped that it will be an information and input material for the Principal, the teaching staff at Ngreco Kediri Elementary School, especially in encouraging students to always improve their achievement motivation more adequately.
\end{abstract}

Keywords: Mastery, expectation, readiness

\begin{abstract}
ABSTRAK
Data penelitian ini diambil dari hasil metode observasi, wawancara kepada Kepala sekolah SDN Ngreco Kediri, Wali Kelas 5. Kesiapan Kurikulum 2013 di SDN Ngreco Kediri, dalam pengamatan pra penelitian yang dilakukan oleh peneliti menunjukkan adanya indikasi yaitu Kurikulum 2013 sudah mulai diterapkan di SDN Ngreco Kediri. Penerapan Kurikulum 2013 tersebut menurut peneliti layak untuk dikaji lebih lanjut. Tujuan dilaksanakannya penelitian ini adalah untuk mengetahui: (1)Untuk mengetahui penguasaan Kepala Sekolah, dan guru tentang kurikulum 2013. (2) Untuk mengetahui kesiapan sekolah dalam implementasikan kurikukulum 2013. (3) Untuk mengetahui penerapan kurikulum 2013 yang dilakukan oleh guru dalam proses pembelajaran. (4) Untuk mengetahui Kendala
\end{abstract}


Pendas : Jurnal IImiah Pendidikan Dasar, ISSN Cetak : 2477-2143 ISSN Online : 2548-6950 Volume III Nomor 2, Desember 2018

yang dihadapi oleh sekolah dalam mengimplementasikan Kurikulum 2013 dan solusi-solusi apa yang diambil untuk mengatasinya. Jenis penelitian ini adalah kualitatif. Sumber data primer dalam penelitian ini adalah hasil wawancara dengan Kepala Sekolah, guru kelas. Teknik pengumpulan data menggunakan teknik wawancara, observasi, dan dokumentasi. Teknik analisis data menggunakan analisis Moleong. Hasil penelitian ini dapat disimpulkan : (1) Kesiapan sekolah dalam Kurikulum 2013 di SDN Ngreco Kediri, dengan menyesuaikan muatan yang terdapat dalam kurikulum 2013 yaitu : tujuan satuan pendidikan, struktur kurikulum, Kompetensi Inti, Kompetensi Dasar, kompetensi mata pelajaran, beban belajar, penguatan tata kelola, penguatan materi, dan karakteristik kurikulum 2013, (2) kesiapan guru terhadap penerapan Kurikulum 2013 di SDN Ngreco Kediri,. Berdasarkan hasil penelitian ini diharapkan akan menjadi bahan informasi dan masukan bagi Kepala Sekolah,para tenaga pengajar di SDN Ngreco Kediri terutama dalam memberikan dorongan kepada siswa agar senantiasa meningkatkan motivasi berprestasi secara lebih memadai.

Kata Kunci : Penguasaan, penerarapan,kesiapan

\section{A. Pendahuluan}

Kurikulum merupakan suatu hal penting dalam sistem pendidikan Indonesia. Kurikulum disusun untuk mewujudkan tujuan pendidikan nasional dengan memperhatikan perkembangan peserta didik, kebutuhan pembangunan nasional, serta perkembangan dan ilmu pengetahuan, teknologi serta kesenian. Hal tersebut bertentangan dengan penjelasan. Undang-Undang Nomor 20 Tahun 2003 tentang Sistem Pendidikan Nasional menyebutkan bahwa kurikulum adalah seperangkat rencana dan pengaturan mengenai tujuan, isi, dan bahan pelajaran serta cara yang digunakan sebagai pedoman kegiatan pembelajaran dalam mencapai tujuan suatu pendidikan tertentu. Berdasarkan pengertian tersebut, ada dua dimensi kurikulum, yangpertama adalah rencana dan pengaturan mengenai tujuan, isi, danbahan pelajaran, sedangkan yang kedua adalah cara yang digunakan untuk kegiatan pembelajaran. Kurikulum 2013 yang diberlakukan mulai tahun ajaran 2013/2014 memenuhi kedua dimensi tersebut.

Permasalahan pendidikan yang muncul dinilai perlu dikembangkan kurikulum baru yaitu Kurikulum 2013. Pengembangan kurikulum 2013 dilakukan karena adanya tantangan internal maupun tantangan eksternal. Tantangan internal terkait tuntutan pendidikan yang mengacu pada 8 Standar Nasional Pendidikan dan 
Pendas : Jurnal IImiah Pendidikan Dasar, ISSN Cetak : 2477-2143 ISSN Online : 2548-6950 Volume III Nomor 2, Desember 2018

faktor perkembangan penduduk Indonesia. Tantangan eksternal berkaitan dengan tantangan masa depan, kompetensi yang diperlukan di masa depan, persepsi masyarakat, perkembangan pengetahuan dan pedagogik.

Pendapat yang berkembang dengan adanya perubahan kurikulum menunjukkan bahwa guru memegang peran penting dalam perubahan kurikulum. Sebaik apapun kurikulum yang dibuat, jika guru yang menjalankan tuganya tidak memiliki kemampuan yang baik, maka kurikulum tersebut tidak akan berjalan dengan baik. Dalam implementasi Kurikulum 2013, kesiapan sekolah mencakup semua kesiapan. Kesiapan tersebut meliputi kesiapan perangkat kurikulum, sarana prasarana sekolah, kesiapan anggaran pendidikan, dan terakhir kesiapan guru.

Berkaitan dengan perubahan kurikulum, (E. Mulyasa, 2013) berpandangan bahwa saat ini kita membutuhkan kurikulum yang berbasis pada kompetensi sekaligus berbasis pada karakter, yang dapat membekali peserta didik dengan berbagai sikap dan kemampuan yang sesuai dengan perkembangan zaman dan perkembangan teknologi. Hal tersebut dimaksudkan agar dapat menjawab tantangan arus globalisasi, berkontribusi pada pembangunan masyarakat, serta adaptif terhadap berbagai perubahan.

Kurikulum baru menuntut guru untuk melaksanakan pembelajaran yang berbasis tematik integratif. Guru juga dituntut untuk tidak hanya memiliki kompetensi profesional, namun juga harus memiliki kompetensi pedagogik, sosial, dan kepribadian. Kurikulum 2013 juga menuntut guru untuk melakukan pembelajaran berbasis pendekatan sains. Kompetensi pedagogik guru perlu untuk diketahui karena kompetensi tersebut berkaitan dengan pengembangan kurikulum serta proses pembelajaran yang dilakukan di dalam kelas. Selain itu, dalam kompetensi pedagogik, guru dituntut untuk memahami karateristik peserta didik, sehingga guru dapat menerapkan pendidikan karakter secara spontan dalam setiap proses pembelajaran agar siswa dapat memenuhi kompetensi sikap.Dengan dasar pemikiran di atas, Kurikulum 2013 menjadi alternatif yang ditawarkan untuk menuju pendidikan yang lebih berkualitas. Kini setiap 
Pendas : Jurnal Ilmiah Pendidikan Dasar, ISSN Cetak : 2477-2143 ISSN Online : 2548-6950 Volume III Nomor 2, Desember 2018

\begin{abstract}
sekolah tengah menyongsong perubahan selangkah demi selangkah untuk menerapkan Kurikulum 2013. SDN Ngreco Kediri merupakan salah satu dari Sekolah Menengah Atas yang telah menerapkan Kurikulum 2013.
\end{abstract}

Atas pertimbangan penulis merasa perlu untuk melakukan kajian dan penelitian secara lebih mendalam terhadap Pelaksanaan Kurikulum 2013. penulis akan mengkaji data-data lapangan yang diperoleh dari tempat penelitian, yaitu SDN Ngreco Kediri Untuk itu penulis memilih judul "Kesiapan Sekolah Dalam Mengimplementasikan Kurikulum 2013 Pada Proses Pebelajaran".

\section{B. Landasan Teori}

\section{Kesiapan Sekolah}

Dalam mengimplementasikan kurikulum, yang lebih penting adalah guru sebagai ujung tombak bahkan bisa menjadi garda terdepan dalam pelaksanaan kesiapan sekolah. Dengan memperhatikan hal tersebut, maka diperlukan pembimbingan yang intensif untuk memandu agar pengamatan akan fakta tidak melahirkan skeptisisme dalam penalaran, dan guru akan menjadi faktor penentu dalam keberhasilan suatu pendekatan ilmuan pada implementasi kurikulum 2013. Oleh karena itu upaya untuk meningkatkan terus kompetensi guru agar mampu menjadi ilmuwan dengan sikap ilmiah menjadi hal yang amat mendesak dalam konteks implementasi kurikulum 2013.

Implikasi dari semua itu, diperlukan upaya pengembangan profesi berkelanjutan agar Guru dapat dan mampu mengembangkan kemamuannya terkait dengan hal-hal berikut : Pertama, kompetensi guru dalam pemahaman substansi bahan ajar/keilmuan (baca: kompetensi Profesional), yang mencakup penguasaan bidang ilmu yang diajarkan. Kedua, meningkatkan kemampuan dalam pengembangan pembelajaran (Kompetensi Pedagogik) melalui metode serta cara tepat dalam mengkonstruksi ilmu, dengan skill yang membawa pada suasana ilmiah dan motivasi siswa yang dapat meningkat.

Dan keberhasilan semua itu perlu dilandasi dengan kepribadian yang edukatif serta kemampuan social yang terus dikembangkan, sehingga pembentukan jejaring baik internal maupun eksternal dapat 
Pendas : Jurnal Ilmiah Pendidikan Dasar, ISSN Cetak : 2477-2143 ISSN Online : 2548-6950 Volume III Nomor 2, Desember 2018

berkembang semakin kuat. Dan semua itu hanya bisa terjadi apabila guru terus bertumbuh menjadi manusia pembelajar karena guru itu adalah Learning Prefesion,dan untuk itu sekolah pembelajar menjadi naungan organisasi yang kondusif bagi terwujudnya hal tersebut.

\section{Implementasi kurikulum 2013}

Implementasi kurikulum 2013 merupakan aktualisasi kurikulum dalam pembelajaran dan pembentukan kompetensi serta karakter peserta didik. Hal tersebut menuntut keaktifan guru dalam menciptakan dan menumbuhkan berbagai kegiatan sesuai dengan rencana yang telah diprogramkan.

\section{Alasan Pengembangan}

Masyarakat Indonesia disuguhi berbagai potret kondisi masyarakat yang memprihatinkan. Melalui media, berbagai kasus bernuansa sadisme, kekerasan, perselingkuhan, penyalahgunaan obat terlarang dan sebagainya.

Pihak mempertanyakan peran pendidikan dalam membangun karakter masyarakat bangsa ini. Sehubungan dengan kondisi tersebut seharusnya pendidikan dan teknologi didayagunakan untuk mempengaruhi pola, sikap, dan gaya hidup masyarakat menjadi lebih baik. (Mulyasa, 2013: 15)

Perbaikan pendidikan nasional yang dirasa masih kurang perlu dilakukan hingga ke akarnya, yaitu pengembangan kurikulum. Menurut Mulyasa (2013: 60), perlunya perubahan kurikulum juga karena adanya beberapa kelemahan yang ditemukan dalam KTSP 2006 sebagai berikut.

a. Isi dan pesan kurikulum masih terlalu padat, ditunjukkan dengan banyaknya mata pelajaran dan materi pembelajaran yang rumit.

b. Kurikulum belum mengembangkan kompetensi secara utuh sesuai dengan visi, misi, dan tujuan pendidikan nasional.

c. Kompetensi yang dikembangkan lebih didominasi oleh aspek pengetahuan.

\section{Metode Penelitian}

\section{Rancangan Penelitian}

Metode penelitian yang digunakan adalah metode penelitian kualitatif. Penelitian kualitatif berpendirian bahwa tidak hanya satu kebenaran yang mutlak. Penelitian kualitatif adalah penelitian yang bermaksud untuk memahami fenomena tentang apa yang dialami 
Pendas : Jurnal IImiah Pendidikan Dasar, ISSN Cetak : 2477-2143 ISSN Online : 2548-6950 Volume III Nomor 2, Desember 2018

subjek penelitian secara holistik, dan dengan cara deskripsi dalam bentuk kata-kata dan bahasa.

\section{Lokasi dan Waktu Penelitian}

Penelitian ini dilakukan di SDN Ngreco Kediri, sedangkan waktu dilaksanakan penelitian ini pada bulan november.

\section{Sumber Data}

Sumber data merupakan subjek dari mana data dapat diperoleh. Sumber data dalam penelitian kualitatif utamanya adalah kata-kata dan tindakan, sedangkan yang lain seperti dokumen dan data-data lainya. Sumber data dalam penelitian ini adalah hasil kuesioner dan wawancara dengan guru. Subjek dalam penelitian ini mencakup guru mata pelajaran di SDN Ngreco Kediri.

Sumber data dalam penelitian adalah subjek dari mana data dapat diperoleh.(Arikunto, 2009: 107) sumber data penelitian yang bersifat kualitatif dalam penelitian ini adalah sebagai berikut :

1). Sumber data primer

Data primer adalah sumber data yang diperoleh secara langsung dari informan di lapangan yaitu melalui wawancara mendalam (indept interview). Wawancara mendalam yaitu mewawancarai narasumber yang di anggap peneliti cocok dengan penelitian tersebut, di sini yang menjadi narasumber yaitu Kepala Sekolah, Guru Mata Pelajaran, serta Peserta didik di SDN Ngreco Kediri.

2). Sumber data sekunder

Sumber data sekunder adalah sumber data yang diperoleh secara tidak langsung dari informan di lapangan, seperti dokumen dan sebagainya. Dokumen tersebut dapat berupa buku-buku dan literature lainnya yang berkaitan serta berhubungan dengan masalah yang sedang diteliti. Data sekunder yang peneliti gunakan dalam penelitian ini berupa dokumen sekolah seperti profil sekolah, RPP, Silbus, dll di SDN Ngreco Kediri.

\section{Cara Pengumpulan Data}

Teknik pengumpulan data merupakan langkah yang paling utama dalam penelitian, karena tujuan utama dari penelitian adalah mendapatkan data. Tanpa mengetahui teknik pengumpulan data, maka peneliti tidak akan mendapatkan data yang memenuhi standar data yang ditetapkan. Dalam penelitian kualitatif, data yang dikumpulkan dalam penelitian ini berupa kata-kata tertulis atau lisan 
Pendas : Jurnal Ilmiah Pendidikan Dasar, ISSN Cetak : 2477-2143 ISSN Online : 2548-6950 Volume III Nomor 2, Desember 2018

dari orang-orang dan perilaku yang dapat diamati.

Cara pengumpulan data merupakan cara yang dipakai untuk mengumpulkan data dengan metodemetode tertentu. Metode yang digunakan adalah sebagai berikut.

1. Metode Observasi

2. Metode Wawancara

3. Metode Dokumentasi

\section{Metode Analisis Data}

Sugiyono,

(2006:335)

menyatakan bahwa analisis data kualitatif ialah proses mencari dan menyusun secara sistematis data yang diperoleh dari hasil wawancara, catatan lapangan, dan dokumentasi dengan cara mengorganisasikan data kedalam kategori, menjabarkan kedalam unit-unit, menyusun kedalam pola, memilih mana yang penting dan yang akan dipelajari, dan membuat kesimpulan sehingga mudah dipahami oleh diri sendiri maupun orang lain. Analisis data dalam penelitian kualitatif dilakukan sejak sebelum memasuki lapangan, selama di lapangan, dan setelah selesai penelitian di lapangan. Analisis data menjadi pegangan bagi penelitian selanjutnya sampai mungkin, teori grounded. Namun dalam kenyataannya analisis data

kualitatif berlangsung selama proses pengumpulan data daripada setelah selesai pengumpulan data. (Sugiyono, 2006: 338).

Analisis data merupakan pengelolaan data yang sudah terkumpul dan diharapkan diperoleh gambaran yang akurat dan konkret dari subjek penelitian. Analisis data kualitatif merupakan upaya bekerja dengan data, mengorganisasikan data, memilah-milahnya menjadi satuan yang dapat dikelola, mensintesiskannya, mencari dan menemukan pola, menemukan apa yang penting, dan memutuskan apa yang dapat diceritakan kepada orang lain.

Dalam penelitian, saat
wawancara peneliti sudah
menganalisis jawaban dari hasil
wawancara. Bila jawaban belum
memuaskan, maka peneliti
memberikan pertanyaan kembali
sampai jawaban dianggap telah
kredibel. Aktivitas dalam analisis data
kualitatif dilakukan secara interaktif
dan berlangsung secara terus
menerus sampai tuntas, sehingga
datanya sudah jenuh. Aktivitas yang
dilakukan dalam analisis data ini
adalah penggolongan data, penyajian
data, dan verifikasi data. Data yang


Pendas : Jurnal Ilmiah Pendidikan Dasar, ISSN Cetak : 2477-2143 ISSN Online : 2548-6950 Volume III Nomor 2, Desember 2018

akan dianalisis sebelumnya dikumpulkan (data collection), data yang dikumpulkan merupakan data yang berasal dari kuesioner, wawancara, dan dokumentasi dari guru Mata Pelajaran Ekonomi di SDN Ngreco Kediri.

\section{Hasil dan Pembahasan}

Penelitian ini mempunyai tujuan utama untuk mengetahui penguasaan, kesiapan, penerapan dan kendala yang dihadapi SDN Ngreco Kediri dalam mengimplementasikan kurikulum 2013. Untuk mencapai tujuan tersebut dalam penelitian ini menggunakan metode wawancara untuk dapat data serta dokumen mengenai implementasi kurikulum 2013 di SDN Ngreco Kediri.

Dalam penelitian ini peneliti dapat mengamati tentang penguasaan, kesiapan penerapan dan kendala kendala yang di hadapi SDN Ngreco Kediri dalam mengimplementasikan kurikulum 2013 khususnya pada proses pembelajaran. Maka pembahasan mengenai Kesiapan sekolah dalam mengimplementasikan kurikulum 2013 sebagai berikut: a. Penguasaan kepala sekolah, wakil kurikulum dan guru mata pelajaran dalam mengimplementasikan kurikulum 2013

Kurikulum pada dasarnya merupakan alat dalam upaya pencapai tujuan pendidikan. Sebagus apapun desain kurikulum itu tergantung pada Penguasaan kurikulum2013 kepala sekolah berperan aktif dalam kuri kulum 2013 dengan mengisyaratkan adanya pemberdayaan segenap komponen sekolah secara terus menerus dan berkelanjutan sehingga sekolah bisa menjalankan kurikulum 2013 yang sesuai dengan baik dan lancar. Kurikulum 2013 ini akan berjalan dengan lancar jika di imbangi dengan penguasaan kepala sekolah dalam isi kurikulum 2013.

Penguasaan kepala sekolah, guru, dan komite sekolah merupakan komponen yang penting dalam upaya merealisasikan kurikulum 2013. Yang sesuai dengan harapan di atas bahwa fungsi pengawas dengan fungsi manajerial pengawas harus mempunyai fungsi kepribadian, supervise manajerial,supervise akademik, evaluasi pendidikan, penelittian, dan pemngembangan,dan social yang diharapkan mampu 
Pendas : Jurnal IImiah Pendidikan Dasar, ISSN Cetak : 2477-2143 ISSN Online : 2548-6950 Volume III Nomor 2, Desember 2018

menjadi mediator antara sekolah dan kedinasan.

b. Kesiapan sekolah dalam implementasi kurikulum 2013

Kemampuan dalam melakukan kesiapan sekolah yaitu dalam persiapan mengajarnya merupakan langkah awal yang harus dimiliki oleh guru dan sebagai muara dari segala pengetahuan teori, ketrampilan dasar dan pemahaman yang mendalam tentang obyek belajar dan situasi pembelajaran.

Guru professional harus mampu mengembangkan persiapan mengajar yang baik, logis dan sistematis karena disamping untuk melaksanakan pembelajaran persiapan tersebut mengemban sehingga guru dapat di pertanggungjawabkan mengenai apa yang dilakukan.

c. Penerapan kurikulum 2013 dalam proses pelajaran

Kegiatan pembelajaran merupakan proses aktif bagi siswa dan guru untuk mengembangkan potensi siswa sehingga mereka akan tahu terhadap pengetahuan dan pada hakikatnya mampu untuk melakukan sesuatu. Dalam kurikulum 2013, pembelajaran merupakan keseluruhan proses usaha belajar dan pembentukan kompetensi peserta didik yang direncanakan. Pada umumnya, kegiatan pembelajaran mencakup kegiatan awal atau pembukaan, kegiatan, penutup dan penilaian.

Pembelajaran ini tidak terlepas dari peran guru. Supaya pembelajaran berjalan dengan lancar, maka seorang guru harus memiliki kompetensi sebagai tenaga pendidik yang profeisonal. Salah satu komponen yang harus dimiliki guru adalah penggunaan strategi atau metode pembelajaran, karena pada dasarnya metode/ startegi sangat diperlukan dalam proses pembelajarannya.

Pada kurkulum 2013 guru harus mampu memberikan materi sesuai dengan metode atau strategi pembelajaran sesuai dengan kurikulum 2013 agar pada pelaksanaan pembelajaran sekolah SDN Ngreco Kediri sudah benarbenar menerapkan metode pemebelajarn ilmiah untuk menunjang pendidikan peserta didik, karena tujuan dari kurikulum 2013 ini adalah menghasilkan peserta didik yang produktif, kreatif,inovatif, melalui penguatan sikap, ketrampilan dan pengetahuan yang terintegrasi. 
Pendas : Jurnal IImiah Pendidikan Dasar, ISSN Cetak : 2477-2143 ISSN Online : 2548-6950 Volume III Nomor 2, Desember 2018

d. Kendala Yang di Hadapi Oleh sekolah dalam impelentasi kurikulum 2013 dan solusi-solusi untuk mengatasinya

Pada perubahan struktur kurikulum 2013 yang berdasarkan pada SKL yang berpengaruh terhadap semua perubahan yang di sekolah dalam pemebelajaranya maupun penilaiannya, konteknya sekolah belum bisa menerapkan kurikulum 2013 secara efektif melainkan secara bertahap dan butuh waktu untuk beradaptasi dalam kurikulum yang baru .

Selain itu, buku sebagai alat penunjang kegiatan sangatlah di perlukan. Namum dalam kurikulum 2013 buku ajar guru dan siswa harus sesuai $\mathrm{KI}$ dan $\mathrm{KD}$ nya agar dalam pembelajaran kurikulum 2013 guru dapat menyampaian materi sesuai dengan yang di harapkan kurikulum 2014 Malah waktu juga mempengaruhi terhadap proses evaluasi pembelajaran. Dengan mengatur waktu dengan baik, maka proses pembelajaran dan evaluasi berjalan dengan baik pula. Evaluasi pembelajaran kurikulum 2013 yang menekankan pada penilaian sikap dan ketrampilan siswa, mengharuskan guru untuk lebih bisa variatif dalam mengelola kelas, dan menjalankan proses pembelajaran. Bukan hanya guru, tapi siswa dituntut untuk aktif dan keratif juga.

\section{E. Kesimpulan}

Berdasarkan data-data dan analisis sebagaimana yang telah diuraikan, maka peneliti dapat menyimpulkan sebagai berikut :

1. Penguasaan kepala sekolah, wakil kepala bagian kurikulum serta dalam mengimplementasinnya kepala sekolah dan wakil kepala sekolah bagian kurikulum, telah merumuskannya dengan matang hal ini dapat dilihat dalam tugas dan perannya dimana dalam tugas dan peranya dapat di ketahui bagaimana kepala sekolah dan wakilnya membimbing, mengawasi dan menjalankan kurikulum 2013 ini dan wakil kepala sekolah dan wakilnya berusaha untuk menguasai isi kurikulum 2013 di SDN Ngreco Kediri agar berjalan dengan efektif

2. Secara umum dalam kesiapan sekolah untuk implementasi kuriulum 2013 SDN Ngreco Kediri telah menyiapkan secara terencana dan matang. Namum dalam pelaksanaannya 
Pendas : Jurnal IImiah Pendidikan Dasar, ISSN Cetak : 2477-2143 ISSN Online : 2548-6950 Volume III Nomor 2, Desember 2018

membutuhkan waktu untuk beradaptasi dengan kurikulum yang baru agar kurikulum 2013 di SDN Ngreco Kediri berjalan dengan efesien. Hal ini, Sekolah telah menyiapkan beberapa diantarannya dalam mensosialisasikan kurikulum 2013 bagi guru dan kepala sekolah. Bukan hanya sosialisasi namun sekolah juga harus siap dalam sistem pemebelajarannya, dalam sarana dan prasarananya yang merupaka pelengkap dalam menunjang kurikulu 2013 ini berjalan secara efektif dan efesien.

3. Penerapan Kurikulum 2013 di SDN Ngreco Kediri, diterapkan dengan menyesuaikan muatan yang terdapat dalam kurikulum 2013 yaitu : tujuan satuan pendidikan, struktur kurikulum, Kompetensi Inti, Kompetensi Dasar, kompetensi mata pelajaran, beban belajar, penguatan materi, dan karakteristik kurikulum 2013. guru terhadap penerapan Kurikulum 2013 di SDN Ngreco Kediri, dapat disimpulkan bahwa Kurikulum 2013 dalam penerapan kurikulum 2013 pada mata pelajaran ekonomi meliputi :
a. Perencanaan pembelajaran dalam mata pelajaran ekonomi

b. Pelaksanaan

kegiatan pembelajaran.
c. Evaluasi hasil belajar atau penilaian.

4. Pada tahap akhir ini yakni kendalakendala yang di hadapi sekolah dalam mengimplementasikan kurikulum 2013 dan solusinya. Untuk kendala yang di hadapi SDN Ngreco Kediri dalam implementasi kurikulum 2013 yaitu:

a. Kendala yang dihadapi SDN Ngreco Kediri dapat dilihat dari segi perangkat awalnya baik itu struktur kurikulumnya, RPP dan buku siswa dalam kurikulum yang baru ini guru di tuntut harus paham isi dari buku sumbernya apakah sudah sesuai dengan KI atau KD. Dan untuk solusinya di harapkan guru dan perangkat sekolah di SDN Ngreco Kediri harus berupaya untuk menyesuaikan dan melakukan pelatihan pada kurikulum 2013.

b. Kendala selanjutnya dalam penilaiannya. SDN Ngreco Kediri beranggapan bahwa dalam penilaian yang baru ini mendapatkan kendala seoalnya pihak sekolah belum mendapatkan kejelasan tentang 
Pendas : Jurnal Ilmiah Pendidikan Dasar, ISSN Cetak : 2477-2143 ISSN Online : 2548-6950 Volume III Nomor 2, Desember 2018

penilaian khususnya pada penilaian model raport. Hal ini meneyebabkan perbedaan pendapat anatara pengawas sekolah degan dan kepala sekolah tentang penyususnan rubric penilaian. Untuk mengantisipasi hal tersebut pihak SDN Ngreco Kediri mencetak format penilaian buku raport yang sesuai untuk kurikulum 2013 ini.

c. Metode pemelajaran merupakan kendala juga dalam penerapan kurikulum 2013, khussnya guru di SDN Ngreco Kediri masih belum paham menegnai metode pembelajaran dalam kurikulum 2013 ini. Hal ini dapat di antisipasi dengan cara guru harus melakukan penguatan pendekatan dalam kurikulum yang baru ini baik dalam sekolah maupun dari pemerintah.

\section{DAFTAR PUSTAKA}

E.Mulyasa. (2013). Pengembangan dan Implementasi Kurikulum 2013. Bandung: Remaja Rosdakarya.
Nasution. (2008). Asas-asas

Kurikulum. Jakarta : Bumi Aksara.

Oemar Malik. (2008). Manajemen pengembangan kurikulum. Bandung: Remaja Rosdakarya.

Barnadib. (1992). Filsafat pendidikan : sistem dan metode. Yogyakarta: Andi Offset.

Nasution,S. (1989). Kurikulum Pengajaran. Jakarta: Bina Aksara.

Undang-undang Nomor 20 tahun 2003 tentang Sistem Pendidikan Nasional

Umar Tirtarahardja. (2005). Pengantar Pendidikan. Jakarta: Rineka Cipta.

Abdullah Idi. (2010). Pengembangan Kurikulum teori dan praktek. Yogyakarta: Arrus Media.

Adiwikarta, S. (1994). Kurikulum untuk abad ke-21. Jakarta:Raja Grafindo.

Nasution, S. (1995). Pengembangan kurikulum. Jakarta: Bumi Aksara.

Subandijah. (1993). Pengembangan dan Inovasi Kurikulum. Jakarta: Raja Grafindo Persada.

Oemar Hamali. (2008). Dasar-dasar Pengembangan Kurikulum. Bandung: Remaja Rosdakarya. 
Pendas : Jurnal Ilmiah Pendidikan Dasar, ISSN Cetak : 2477-2143 ISSN Online : 2548-6950

Volume III Nomor 2, Desember 2018

Moleong LJ. (2007). Metodologi

Penelitian Kualitatif.

Bandung:Remaja Rosdakarya.

Sugiyono. (2006). Metode Penelitian

pendidika Kualitatif. Bandung:

Alfabeta.

Ingridwati Kurni, dkk. (2007).

Perkembangan Belajar Peserta

Didik. Jakarta:Depdiknas 